The purpose of this quiz is to provide a convenient means of self-assessment of your reading of the scientific content of this issue of $J A O A$. Enter your answers to the questions in the spaces provided so that you can easily check them with the answers that will be published next month.

To apply for CME credit, transfer your answers to the application form and answer sheet on page 916 and mail it to the CME office. So that you may complete this self-assessment in privacy, use only your member number to apply for CME credit. The CME office will record only the fact that you have completed the selfassessment test. Any grading will be done by the Editorial Department only for the purpose of planning areas of study which may be helpful to cover in future issues of JAOA

1. Denton and associates estimated that of prostates removed for benign disease about what percentage were cancerous?

(a) $15 \%$

(b) $20 \%$

(c) $25 \%$.

(d) $30 \%$

(e) None of the above.
2. On transrectal ultrasonograms of the prostate, most carcinomas appear as which of the following?

(a) Hyperechoic.

(b) Mixed echoic.

(c) Isoechoic.

(d) Hypoechoic.

(e) A lamp-shade effect.

3. Papanicolaou smears are considered adequate if the slides contain either endocervical cells or metaplastic cells.

(a) True.

(b) False.

4. Papanicolaou smears should include a vaginal sample.

(a) True.

(b) False.

5. A common route of prostatic metastases to the testis is direct invasion.

(a) True.

(b) False.

6. The most common nonlymphomatous secondary tumor of the testicle originates from which of the following?

(a) Lung.

(b) Colon.

(c) Kidney.

(d) Prostate.

(e) Penis.

7. Multiple intracranial aneurysms occur in what percentage of patients. (c) $40 \%$.

(d) $60 \%$.

(e) $80 \%$.

8. When multiple aneurysms are found angiographically, the one most likely to rupture is the larger one.

(a) True.

(b) False. 


\section{ADVANCE CONVENTION REGISTRATION FORM}

96th Annual Convention and Scientific Seminar

American Osteopathic Association

See reverse side for instructions and further information

NEW ORLEANS, LOUISIANA

OVEMBER 3-7, 1991

AOA No

AME AND OFFICE ADDRESS (Print Clearly)

City \& State

Zip Code

\section{CHECK YOUR REGISTRATION CATEGORY AND THE CATEGORY FOR YOUR GUESTS: ENCLOSE CHECK FOR FEES}

\section{merican Academy of Osteopathy}

SECTION I (AOA MEMBERS)

Member.

Guest

merican Osteopathic Academy of Addictionology

Member

Guest.

merican Osteopathic College of Allergy and Immunology

Member

Guest.

merican Osteopathic College of Dermatology

Member.

Guest.

merican College of Osteopathic Emergency Physicians

Member.

Guest.

merican College of General Practitioners in Osteopathic

Medicine and Surgery

Member.

Guest.

$\$ 275 \dagger$

$\$ 150+t$

$\$ 295 \dagger$

$\$ 170+\dagger$

Membe

$\$ 345 t$

$\$ 220+t$

$\$ 275 t$

$\$ 140+t$

$\$ 300+$

$\$ 175+t$

$\$ 250^{*}$

$\$ 125^{\star \star}$

$\$ 250 \dagger$

$\$ 125+t$

\section{SECTION II}

American Osteopathic Association

7. Member.

Adult Guest - With AOA tickets

Adult Guest - Without AOA tickets

$\square$ Juvenile Guest

口 Intern

$\square$ Resident

$\square$ Student.

$\square$ Adult Guest of Intern, Resident or Student

- Associate Member

口 Nonmember

$\$ 250^{*}$

$\$ 125^{\star *}$

no fee +

no fee +

no fee +

no fee +

no fee +

no fee +

$\$ 75 \#$

$\$ 640^{*} \ddagger$

Auxiliary to the AOA

$\square$ Member - With AOA tickets

$\$ 155 t+$

no fee +

\$195tt‡

Non-Member

\section{SECTION III}

Association of Osteopathic State Executive Directors

$\square$ Member - Without AOA tickets.

no fee +

$\square$ Guest - Without AOA tickets. no fee +

Canadian Osteopathic Association

\section{SECTION IV}

$\square$ Member...

Nonmember

$\$ 250^{*}$

$\$ 640^{\star} \neq$

\section{Research Conference}

Member

$\$ 70+$

Note: DO Research Conferees seeking CME credit MUST register in Section II and pay the applicable member registration fee.

\section{KEY TO SYMBOLS}

* Includes tickets, for one person, to AOA President's Banquet and Entertainment and Alumni Luncheon.

* Includes tickets, for one person, to AOA President's Banquet and Entertainment and AOA Entertainment for Spouses.

† Includes tickets, for one person, to AOA President's Banquet and Entertainment, Alumni Luncheon and all social functions planned by this individual group.

t† Guests receive tickets to AOA President's Banquet and Entertainment, AOA Spouses Entertainment, and all social functions planned by this individual group.

+ Individual tickets for social functions may be purchased.

\# Includes ticket, for one person, to AOA President's Banquet and Entertainment.

‡ See registration rules on reverse side.

COMPLETE the above FORM (see instructions on reverse side), ATTACH CHECK made PAYABLE TO THE AMERICAN OSTEOPATHIC ASSOCIATION, to COver appliable registration fees, and RETURN TO:

Convention Office • American Osteopathic Association • 142 East Ontario Street • Chicago, Illinois 60611

Registration packets will be mailed out prior to the convention to those who register in advance. Advance registration forms must be received no later than September 27,1991 . There will be a $\$ 25.00$ late charge for registration on site. A full refund on cancellations will be made if AOA is informed in writing. 


\section{REGISTRATION INSTRUCTIONS}

\section{THOSE WHO MAY REGISTER}

- Members of the American Osteopathic Association, or the Canadian Osteopathic Association, and registrants who attend the Researc Conference, their adult guests and children.

- Osteopathic physicians who are NOT members of the AOA may register, but are required to pay a fee of $\$ 640.00$. Osteopathic physicians if eligible, may thereupon apply for AOA membership at the registration desk and, if they are accepted into membership, $\$ 390.00 \mathrm{c}$ the Nonmember registration fee will be applied to their annual dues. Membership in the Canadian Osteopathic Association may substitut for AOA membership if the doctor is located in Canada.

- Spouses of osteopathic physicians who are NOT members of the Auxiliary of the American Osteopathic Association may register bL are required to pay a fee of $\$ 195.00$. The nonmember registration fee will be applied to the annual AAOA dues.

- Students and their guests.

- Associate members.

- State Osteopathic Executive Directors.

- Research Conference attendees.

- Commercial and scientific exhibitors.

\section{HOW TO SELECT REGISTRATION CATEGORY}

Sections, I, II, III, IV, and V

Check ONLY ONE category for your registration. Participating affiliated organizations are listed under Section I of the form. The Americar Osteopathic Association registration is under Section II, and other categories are listed under Sections III to V. Regardless of the categon you check, you are entitled to attend ANY of the didactic sessions put on by ANY of the participating organizations. Although mem bership in a participating affiliated organization is not a requirement to register for the group, AOA membership (or if a doctor is from Canada, Canadian Osteopathic Association membership) is a requirement for registration in ANY of the practice affiliates under Sectior I, except for those who have paid the higher Non-member registration fee plus any additional "affiliate" fee, if applicable.

If you are a member of two of the participating affiliated organizations under Section I and wish to register for both, you may do sc by paying TWO registration fees - one for each group. In such case, CME credit will be allowed for only ONE of the two groups.

\section{GUESTS:}

In addition to checking your category, check the category for all your guests (being sure to indicate the guest's name in the space providec on the form).

1. The full member's registration fee does NOT include tickets for anyone other than the member.

2. Guests are to be registered either by paying a fee and receiving tickets, or by NOT paying a fee and NOT receiving tickets ("Adult Guest - NO tickets" category, under Section II of the form).

3. If the member's guest is to have the same tickets as the member, then check the guest category for the group under which the member is registering and pay the fee indicated. In such case, however, the member fee includes an Alumni Luncheon ticket, but the Guest fee does NOT, but tickets may be purchased separately.

4. In addition, the guest registration fee covers a ticket to the AOA Entertainment for Spouses. Those guests who do not pay a registration fee may purchase separate tickets to meal functions.

\section{TICKETS COVERED BY REGISTRATION FEE}

The fees shown on the registration form are followed by symbols to indicate the tickets which are covered by the fees. To interpret the symbols, see boxed "Key to Symbols". 


\section{6th Annual Convention and Scientific Seminar}

Co-Chairs Doctors Martin J. Porcelli, Sidney Malet and Eugene Locken

\section{Anticipating $29 \mathrm{hrs}$ Category 1-A CME Credit}

\section{October 4-6, 1991}

Hyatt Regency Hotel

Irvine, California

Topic: General Medicine

Featuring: Distinguished Speakers

Workshops on Flexible Sigmoidoscopy and Colposcopy

For registration information, call (714) 620-1955

or write: M. Jay Porcelli, D.0., FACGP/Convention Information

180 W. Willow Street, Pomona, CA 91768

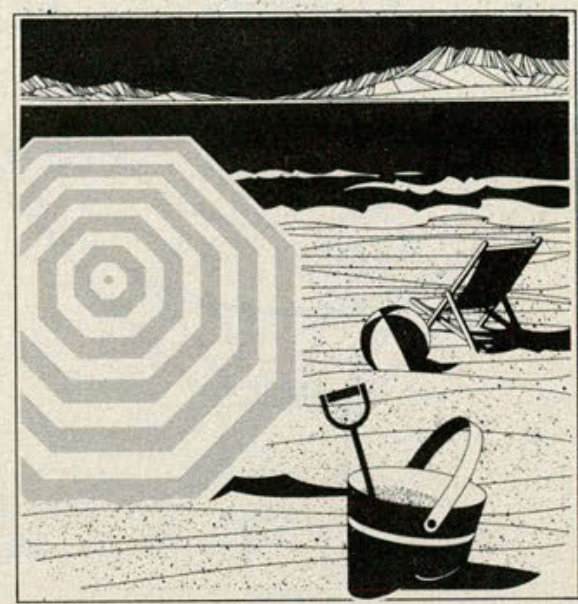

American Osteopathic Association-Continuing Medical Education

\section{CERTIFICATION OF HOME STUDY}

his is to certify that I,

(Please print)

ompleted the following activity for AOA CME credits.

ype of activity

such as reading or listening):

Jame of journal(s) or audiotape and date(s) of issue(s):

One-half CREDIT may be granted for each issue or tape)
The Home Study form is intended to document individual reading of recognized scientific journals, listening to approved audiotapes, and other approved home study courses and programs under the criteria described for Category 2-B.

Only one type of home study, such as reading, should be indicated on a single form, though multiple issues of scientific journals may be listed.

This form should not be used, however, when CME quiz application forms and answer sheets for the AOA journal are submitted separately.

\section{FOR OFFICE USE ONLY}

Category 2-B Credits

Date

Program No. AOA No.

Physician's Name

MAIL TO: AOA Division of CME, 142 East Ontario Street, Chicago, IL 60611-2864

KEEP A DUPLICATE FOR YOUR RECORDS!

Please refer to the revised CME GUIDE for additional information. 


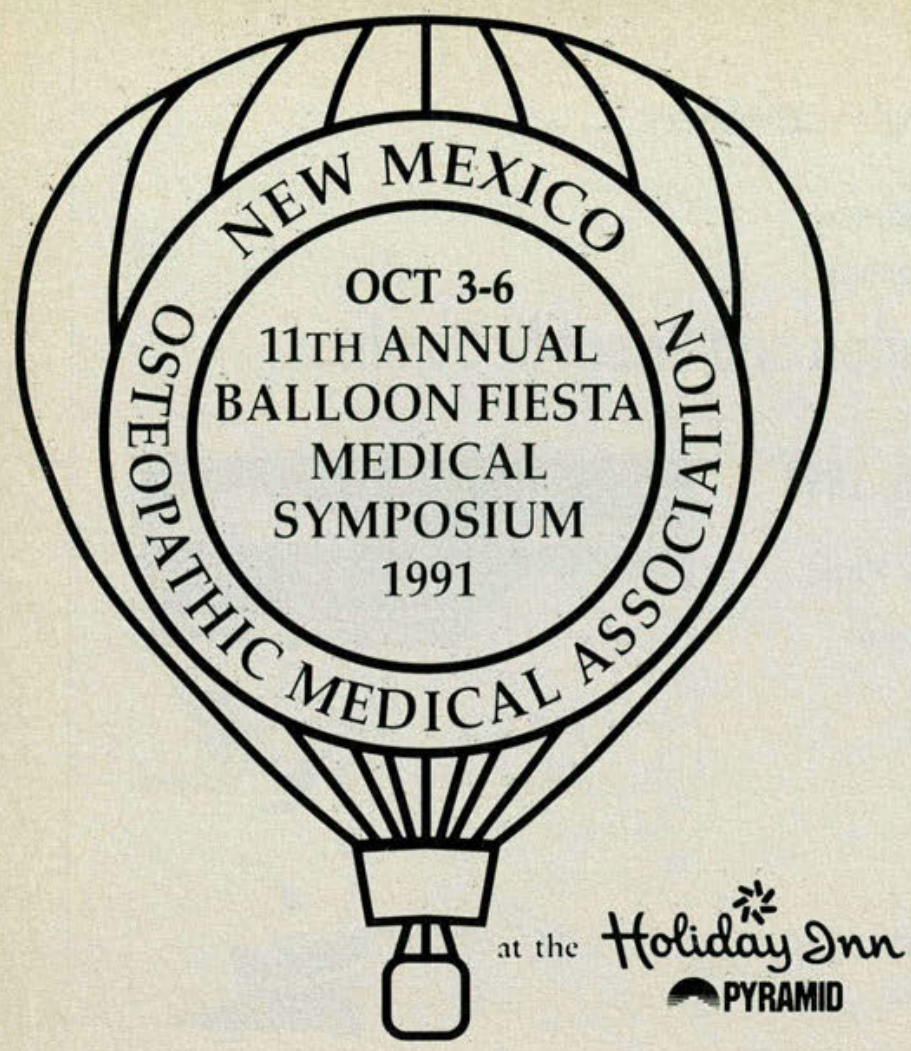

Anticipating 22 Hours

Category 1-A CME Credit, AOA Approved

Program Chairman

Dr. David C. Leech

TOPICS:

OMT Workshop, Internal Medicine, Wilderness Medicine, Medical History,

Aerospace Medicine, and

General Practice Updates

For registration information, call or write:

NMOMA

Symposium Information

P.O. Box 3096

Albuquerque, NM 87190-3096

(828) 898-1905

\section{JAOA CME QUIZ APPLICATION FORM}

COMPLETE THE APPLICATION FORM AND ANSWER SHEET BELOW FOR CME

CREDIT (1 HOUR).

"Certification of Home Study" may be submitted with this application form to save postage.

Cut Out and Mail to: American Osteopathic Association

Attn: Division of CME

142 East Ontario Street

Chicago, IL 60201-2864

Member number 00 (see membership card)

Answer Sheet to September 1991 JAOA CME Quiz

1. $a b c d e$

2. $a b c d e$

3. $\mathrm{ab}$

4. $\mathrm{ab}$

5. $\mathrm{ab}$

6. a bcde 7. abcde

8. a b 
